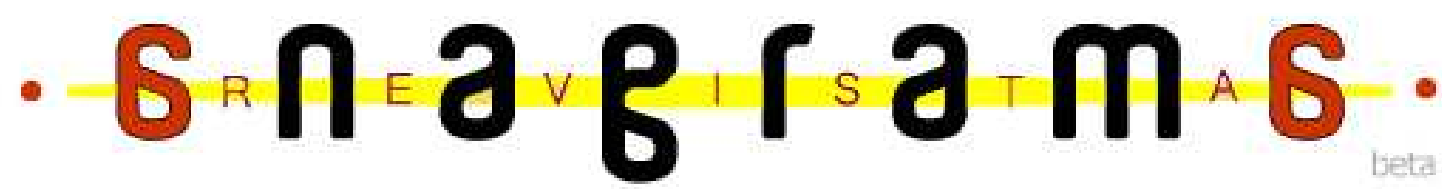

\section{Análise dos Filmes Luz de Invernoe 0 Sétimo Selo de Ingmar Bergman atraués do Olhar do Existencialismo de Jean-Paul Sartre: angústia, ausência de Deus, morte e liberdade} Ana Catharina Gomes França ${ }^{1}$

\section{Resumo}

O cinema apesar de ter uma linguagem própria permite-se diversas possibilidades de conexão com outros universos de estudo. Assim, é possível analisar filmes com a filosofia como foco. Este artigo pretende analisar Luz de Inverno e Sétimo Selo de Bergman através do existencialismo sartreano no que diz respeito à angústia, liberdade, ausência de Deus e morte, tendo como base os livros $O$ Existencialismo é Um Humanismo e O Ser e O Nada. Através do método fenomenológico e bibliográfico pretende-se apontar os elementos em que Sartre está presente na obra bergniana. $\mathrm{O}$ método de análise fílmica utilizado foi o logopático baseado no livro O Cinema Pensa de Julio Cabrera.

Palauras-chaue: Análise; Bergman; Existencialismo; Logopático; Sartre.

Introdução

É inegável a importância da filmografia de Ingmar Bergman no meio cinematográfico abordando temas intrínsecos a existência humana. No outro lado está Jean-Paul Sartre, filósofo existencialista contemporâneo de Bergman e um dos maiores pensadores do século passado. Por viverem na mesma época, evidentemente estavam inseridos no mesmo contexto histórico, período duramente marcado pelas guerras mundiais, pela instabilidade da Guerra Fria e pelo fervor de 68, fato relevante na seleção de ambos como foco da análise.

\footnotetext{
${ }^{1}$ Graduanda em cinema pela Universidade Anhembi Morumbi. Orientador: Prof. Dr. Gelson Santana Penha, graduado em Comunicação Social pela Universidade Federal Fluminense com habilitação em Cinema, Doutor em Ciência da Comunicação pela ECA/USP.
} 
Abordar o existencialismo como um todo seria inviável para um artigo, por isso, a bibliografia sartriana utilizada resume-se no Existencialismo é Um Humanismo e O Ser e o Nada. Dos inúmeros temas existencialistas, angústia, liberdade, ausência de Deus e morte foram delimitados para a análise nos filmes Luz de Inverno e Sétimo Selo através da metodologia fenomenológica e bibliográfica.

O cinema possui seu vocabulário próprio de conceitos e imagens que compõe sua linguagem. A filosofia, por sua vez, possui outra linguagem, a escrita. Contudo, segundo Cabrera "as técnicas do cinema possibilitam a efetivação das características "filosóficas'" (2006:30), através do que o autor chama de conceito-imagem: "um tipo de 'conceitovisual' estruturalmente diferente dos conceitos tradicionais utilizados pela filosofia escrita" (2006:21). Assim, deve-se ter uma compreensão "logopática" dos filmes, ou seja, analisálos racional e afetivamente ao mesmo tempo, deste modo "há um elemento experiencial (não 'empírico') na apropriação de um problema filosófico" (2006:17) de forma que "não desaloja o racional: redefine-o" (2006:18). Ele ainda afirma que "Cinema e literatura, do ponto de vista ultra-abstrato adotado pela filosofia, são a mesma coisa. Mudam as técnicas, as linguagens, as respectivas temporalidades etc. A pretensão à verdade universal é a mesma" (2006:29). O presente trabalho tem por objetivo unir o cinema com a filosofia, especificamente a existencialista de Sartre, através da análise de duas das principais obras de Ingmar Bergman.

\section{Análise Luz de Inverno}

Segundo filme da "Trilogia do Silêncio", Luz de Inverno é exibido num contexto de Guerra Fria durante um período de intensas mudanças políticas. Baseado no clássico Diário de um Pároco de Aldeia, de Robert Bresson. O longa-metragem de Bergman tem no diálogo sua base, é a narrativa que move o filme.

Numa pacata aldeia sueca, Gunnar Bjornstrand interpreta Thomaz, um pastor que vive uma crise de fé. Após a morte de sua mulher, Thomaz fica descrente de Deus. Ele declara isto numa conversa com Jonas, um pescador local, que foi até a igreja para buscar apoio para sua crise existencial, ele diz temer a bomba atômica que os chineses possivelmente teriam. Ao invés de dar suporte a Jonas, o pastor expressa toda sua descrença no que ele acreditava ser Deus. Na sequência desta conversa o pescador comete 
suicídio com um tiro de rifle na cabeça. O conflito do pastor é acompanhado durante todo o filme por Marta, sua ajudante apaixonada.

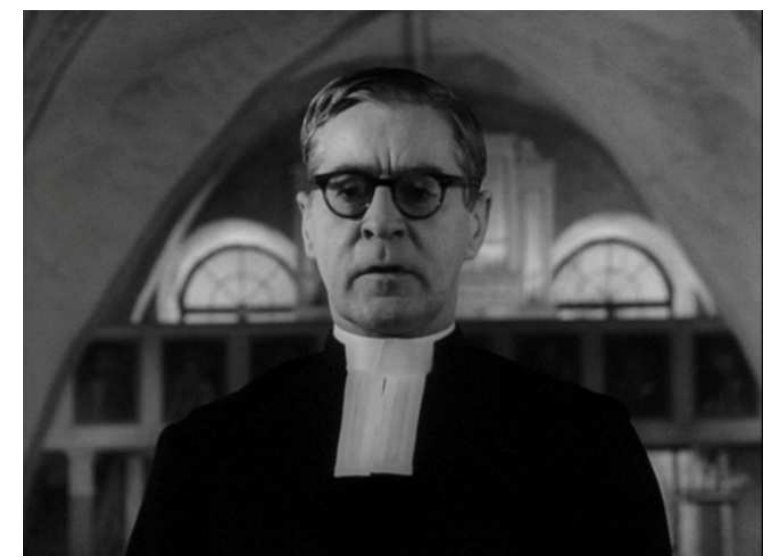

Figura 1

Bergman opta por iniciar o filme com o pastor centralizado ministrando uma missa (Figura 1). Sua expressão de contragosto e insatisfação com são visíveis. O diretor ao enquadrar o plano não se preocupa com a regra dos terços da fotografia, há monotonia e falta de dinâmica ao posicionar o ator no centro, não é uma imagem fluida, natural, confortável. Neste primeiro plano, na composição do quadro, pode-se ter uma introdução de como será filme, o estado de espírito não confortável de Thomaz com seu ofício.

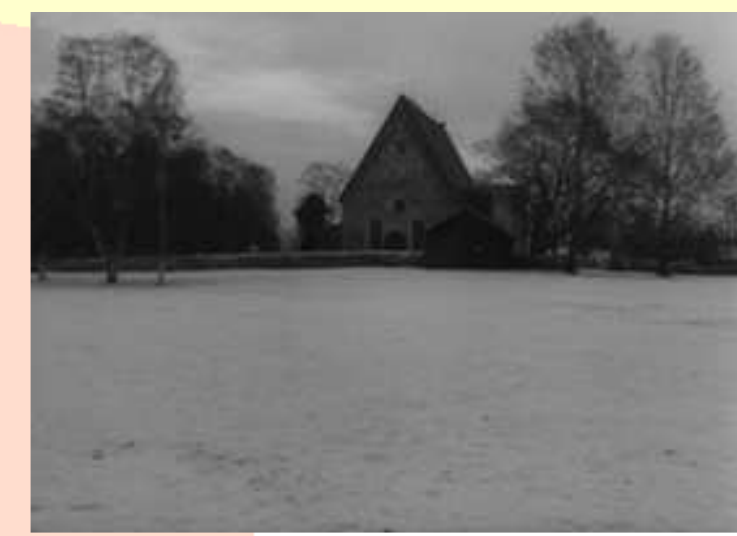

Figura 2

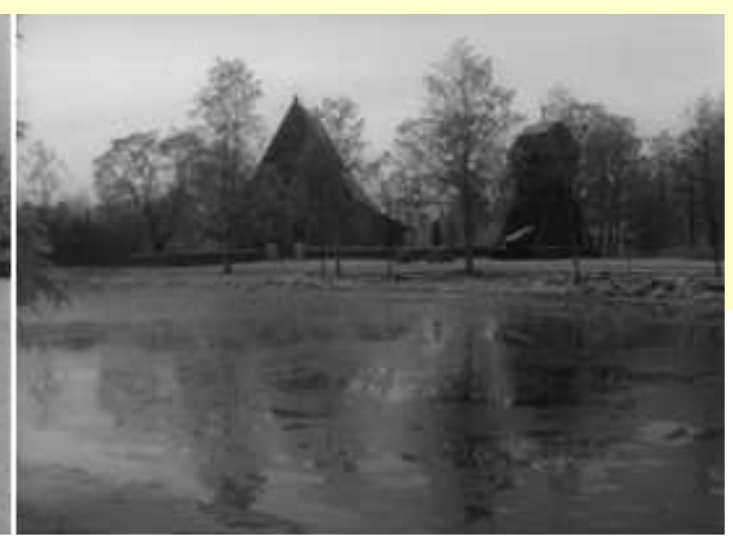

Figura 3

Durante a missa, enquanto o pastor reza o Pai Nosso, imagens da região da aldeia vazia são mostradas (Figuras 2). O que é possível entender como a ausência de Deus. A voz de Thomas está sozinha, não há ninguém lá fora. No momento em que ele diz "e não deixeis cair em tentação, mas livrai-nos do mal" a imagem do mesmo rio onde Jonas se suicidou ao lado é mostrada (Figura 3), o que nos leva a entender que Deus também não estava presente para livrar o pescador da morte. Nisso está o princípio básico do existencialismo ateu de Sartre onde "a existência precede a essência", ou seja: 
O homem primeiramente existe, se descobre, surge no mundo; e só depois se defini. O homem, tal como o concebe o existencialista, se não é definível, é porque primeiramente não é nada. Só depois será alguma coisa e tal como a si próprio se fizer. Assim, não há natureza humana, visto que não há Deus para a conceber. (SARTRE, 1978: 216)

Há elementos na mise-en-scène que podem representar essa ausência de Deus como nos diversos planos em que a imagem de um Jesus Cristo com uma expressão marcante, crucificado e morto aparece atrás de Thomaz (Figuras 4,5,6 e 7).

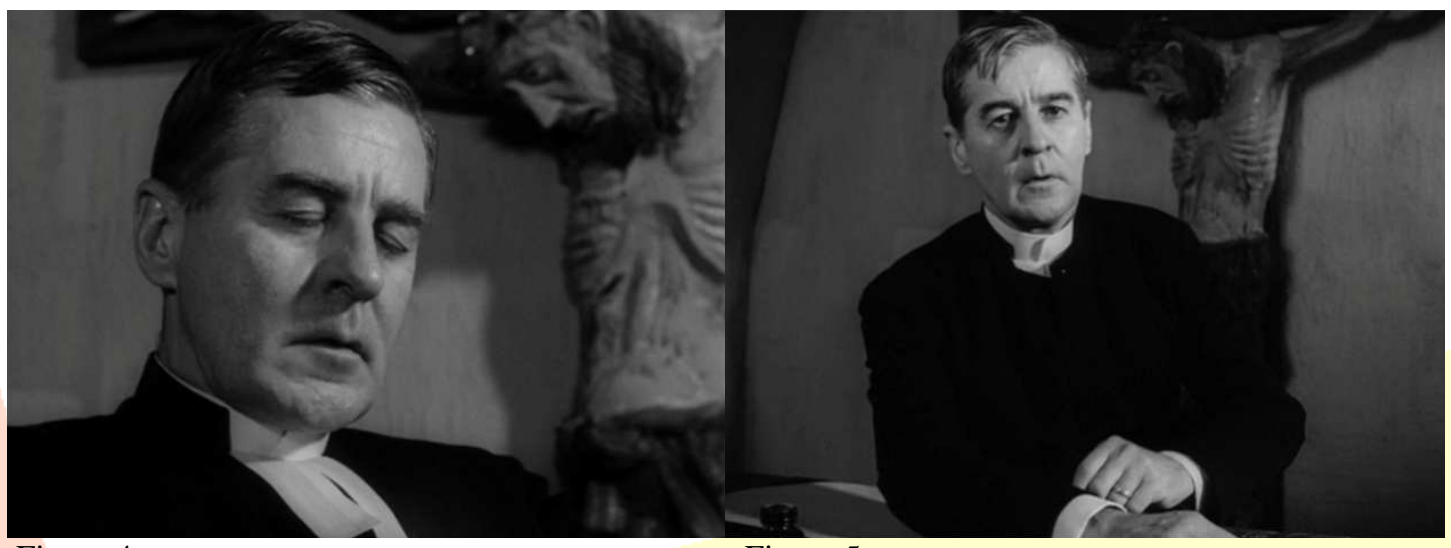

Figura 4

Figura 5

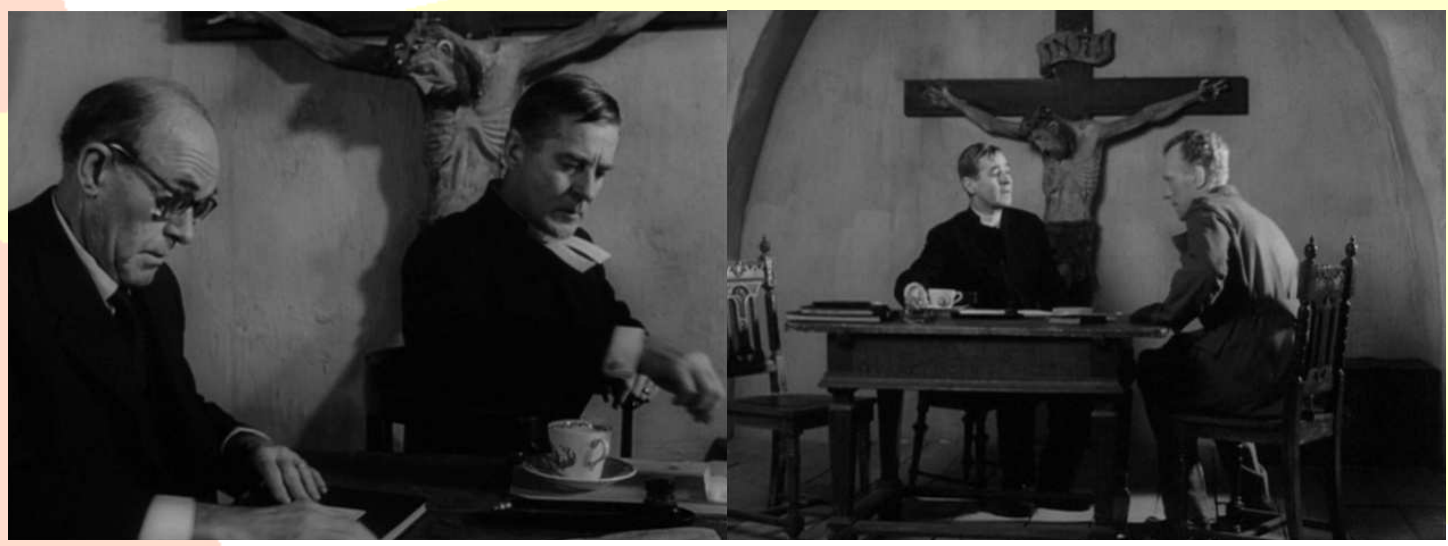

Figura 6

Figura 7

Quando o pescador busca auxílio, para entender sua crise, com Thomaz, o pastor, incomodado consigo mesmo, declara não ser um bom sacerdote e diz que tinha fé numa imagem improvável e particular de um Deus paterno, mas quando confrontava-o com questões reais, como a Guerra Civil Espanhola que viveu quando foi pastor em Lisboa, percebia que Ele se transformava em algo feio e revoltante.

Essa crise causada pela descrença pode ser explicada no existencialismo de Sartre (1978: 226):

[...] é muito incomodativo que Deus não exista, porque desaparece com ele toda a possibilidade de achar valores num céu inteligível; não pode existir já o bem a priori, visto não haver uma consciência infinita e perfeita para pensá-lo; não está escrito em parte alguma que o bem existe. 
O pastor prossegue perguntando se Deus existisse se isso realmente faria alguma diferença. O princípio do existencialismo diz que "Se Deus não existisse, tudo seria permitido" (Dostoiewsky apud Sartre, 1978: 227). Thomaz continua dizendo que a vida se tornaria compreensível e seria um alívio onde a crueldade, solidão e o medo seriam coisas claras e transparentes. A filosofia de Sartre faria mais sentido no mundo vivido do Pastor, já que não existiria nenhum bem a priori, como dito acima, que entrasse em contradição com realidades como a guerra, por exemplo.

Ele ainda cita que o sofrimento é incompreensível e que não exige explicação nem um criador e provedor da vida. Por conseguinte pode-se perceber a evidente semelhança desta sequencia do filme com a filosofia de Sartre, a impossibilidade de algo metafísico ser responsável pela existência do universo e do próprio homem.

Pouco depois, quando Jonas vai embora, Thomaz se pergunta "Deus, Deus, por que me abandonaste?". Tratando-se do tema abandono, Sartre diz que o ser humano pode sentilo quando se dá conta da própria liberdade, das suas escolhas, quando percebe que é responsável por si mesmo, o que acontece com o pastor. Surge, então, a angústia:

É nesse sentido e diante desse sentimento de abandono que Sartre vai falar da angústia. Não no sentido de uma depressão, tristeza ou coisa que o valha, mas no sentido de perceber essa indeterminação absoluta e se encontrar sozinho dentro do mundo para decidir sobre seu próprio destino. Esse sentimento que nos deixa em meio ao nada é que nos traz angústia. (OLIVEIRA, 2010: 70)

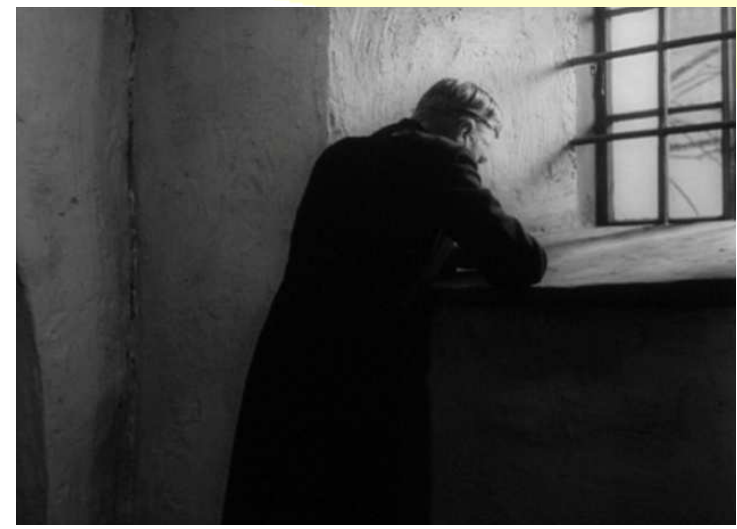

Figura 8 


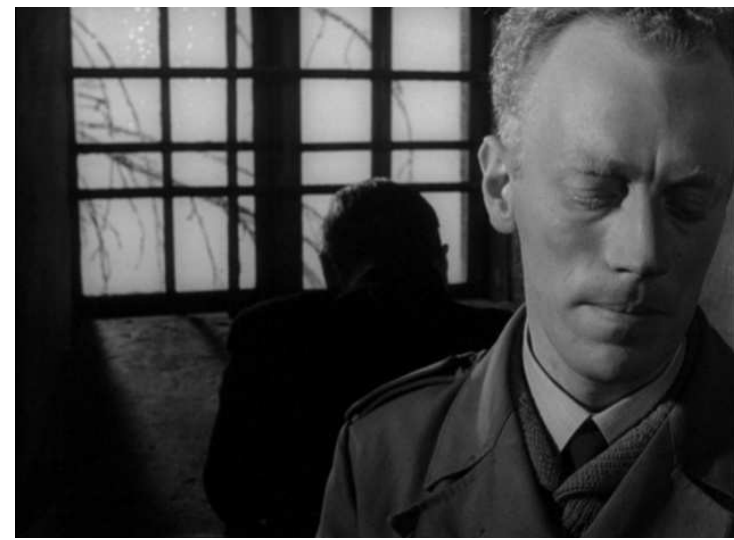

Figura 9

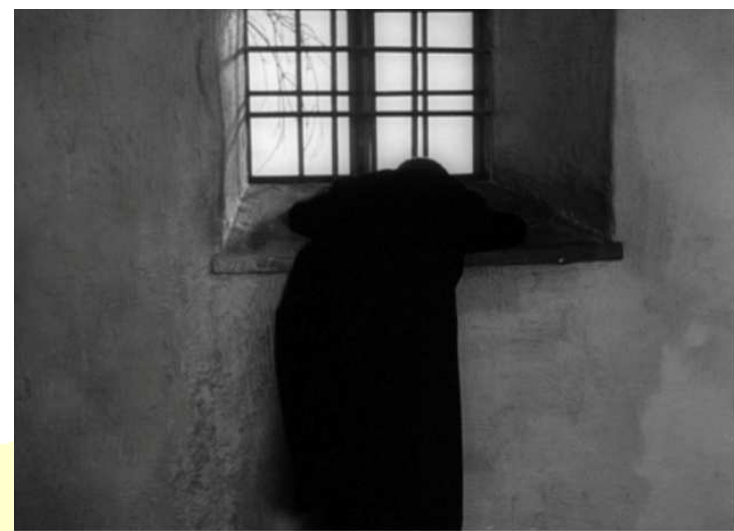

Figura 10

Nas figuras 8, 9 e 10 é possível ressaltar o sentimento de angústia sendo representado sempre que Bergman opta por filmar o personagem em crise existencial na igreja próximo a parede, buscando respirar numa janela com grades.

O longa-metragem possui muito mais cenas internas do que externas, aumentando a sensação de angústia no espectador. Um dos únicos momentos que Thomaz é filmado ao ar livre acontece quando ele é chamado para verificar o corpo do pescador que tirou a própria vida.

Em relação ao suicídio de Jonas, Sartre diria que "se nada me constrange a salvar minha vida, nada me impede de jogar me no abismo" (SARTRE, 1997: 76). Esta citação faz parte de um exemplo dado por Jean-Paul Sartre sobre como o nada vem ao mundo, ou seja, como os seres humanos tomam decisões. O exemplo é baseado numa pessoa na beira do abismo em dúvidas sobre se atirar ou recuar:

Meus olhos, percorrendo o abismo de alto a baixo, mimetizam minha possível queda, realizando-a simbolicamente; ao mesmo tempo, a conduta suicida, pelo fato de converter-se em "meu possível" possível, faz surgir por sua vez motivos possíveis para adotá-la (o suicídio fará cessar a angústia). (SARTRE, 1997: 76) 
O pescador sofre de "angústia ante o futuro" (SARTRE, 1997:76), por ser livre para escolher e não suportar o peso de sua liberdade, se mata.

Marta parece ser a única que sempre foi descrente em relação a um determinismo, a uma essência que precede a existência. Há uma fala sua no filme em que diz que Deus nunca falou porque Ele não existe. Marta também afirma que Deus e Jesus para ela eram noções vagas e que cresceu numa família com outros princípios.

No fim do filme Thomaz e seu ajudante conversam sobre Jesus Cristo, o segundo diz "Sinto que ele sofreu muito mais em outro aspecto. Ser abandonado quando precisa contar com alguém. Isto deve ser extremamente doloroso. Mas o pior ainda estava por vir. Quando Cristo foi pregado na cruz, em meio ao sofrimento ele gritou: 'Deus, meu Deus! Por que me abandonaste?'. Ele achou que seu pai o havia abandonado. Achou que tudo que havia pregado era mentira. Nos momentos que antecederam sua morte, Cristo teve dúvidas. Certamente, aquele deve ter sido seu maior sofrimento. Deus ficou em silêncio”. Neste trecho da fala do ajudante pode-se concluir que Jesus partilhou do mesmo sentimento de abandono que Thomaz.

Negris afirma, em relação a falta da trilha sonora, que "a ausência de um fundo musical representa o silencio de Deus, a angústia de um Deus que não fala aos seus fiéis". E Sartre em seu documentário Sartre Por Ele Mesmo diz "O silêncio é reacionário no sentido de que é a recusa em se comunicar, o desejo de ser de pedra, de ser um ser que é como uma estátua". Na relação da falta de trilha musical com a ausência de Deus encontrase um recurso da linguagem cinematográfica que funciona como uma ferramenta para a filosofia.

\section{Análise - O Sétimo Selo}

Este foi o principal filme que levou Ingmar Bergman ao reconhecimento mundial. Lançado em 1957, próximo a Segunda Guerra Mundial, das ameaças nucleares, dos traumas do holocausto e da mortandade desencadeada na guerra.

Em meio a este clima, Bergman realiza Sétimo Selo. Filme habituado na Idade Média assolada pela peste. Após dez anos, dois cavaleiros voltam das Cruzadas, Jöns (Gunnar Bjornstrand) e Antonius Block (Max Von Sydow), o protagonista, que no início é convidado pela morte à encarar uma partida de xadrez que acontecerá durante toda a trama. $\mathrm{Na}$ volta à aldeia eles encontram um grupo de teatro intinerante composto pelo ator Jof, sua 
mulher Mia e o bebê Michael. Durante a trama, Block se questiona sobre a vida enquanto tenta ganhar o jogo contra a morte.

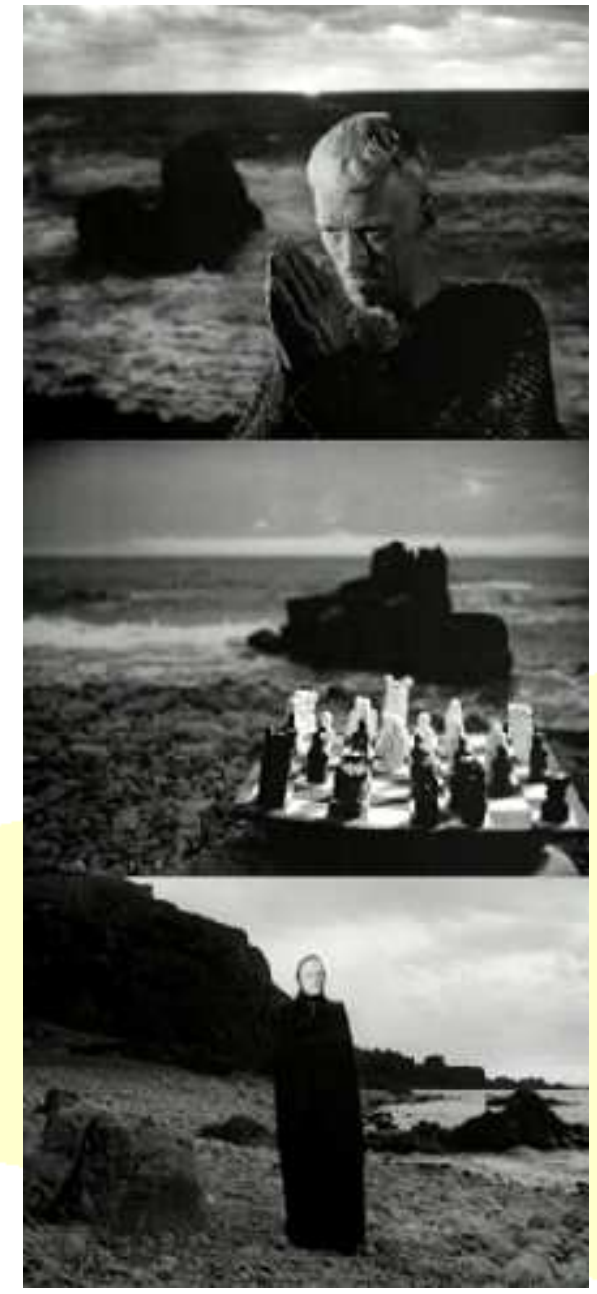

Figura 11

No início do longa-metragem, Block reza e logo após uma panorâmica, um tabuleiro de xadrez é mostrado. Em seguida a morte aparece. Pode-se perceber nesta sequência (Figura11) sem diálogos que o cavaleiro ora em vão, pois nos planos seguintes não há nenhum indício de Deus, somente o jogo com a morte. Fato comprovado ao longo do filme. Mais uma vez está presente a temática sartriana em relação a ausência de uma essência que precede a existência. A morte está personificada, não há nenhuma intermediação divina.

Dentre os diversos personagens, o ator Jof é o único que vê alguma imagem que represente o divino, contudo o plano em que aparece sua visão, a Virgem Maria com o menino Jesus, é posto em prova quando Mia ao escutar os relatos do marido desconfia, pois ele já havia sido pego em flagrante mentindo sobre aparições outras vezes. E mesmo 
se sua visão tivesse ocorrido de fato, este personagem é sempre zombado por todos, não é levado a sério, como vemos mais para frente quando ele é obrigado a imitar um urso num bar.

Block vai ao confessionário da igreja da aldeia para desabafar com o monge, mas é a morte quem está lá, escutando sem que o cavaleiro perceba. Ele indaga porque não consegue ficar livre de Deus, mesmo Ele sendo uma falsa realidade. Antonius ainda relata que gostaria que Deus estendesse as mãos para ele e mostrasse seu rosto, mas que $\mathrm{O}$ chama no escuro e ninguém o ouve. A morte desfarçada de monge responde, sugerindo que talvez não tenha ninguém. Apesar de o cavaleiro afirmar que Deus é uma realidade inexistente, ele continua insistindo neste determinismo, o que Sartre chamaria de má-fé. Aquele que mesmo tendo consciencia da sua liberdade, a nega e continua acreditando em algo anterior a sua existência. "O ato primeiro de má-fé é para fugir do que não se pode fugir, fugir do que se é”. (SARTRE, 1997:118)

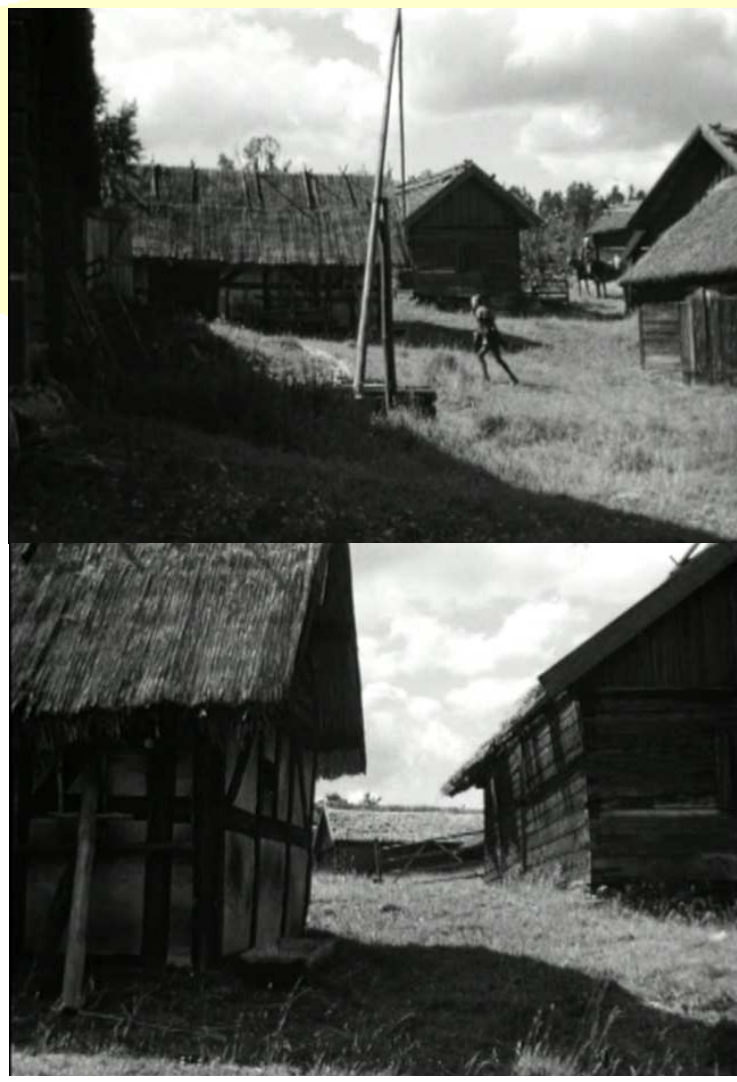




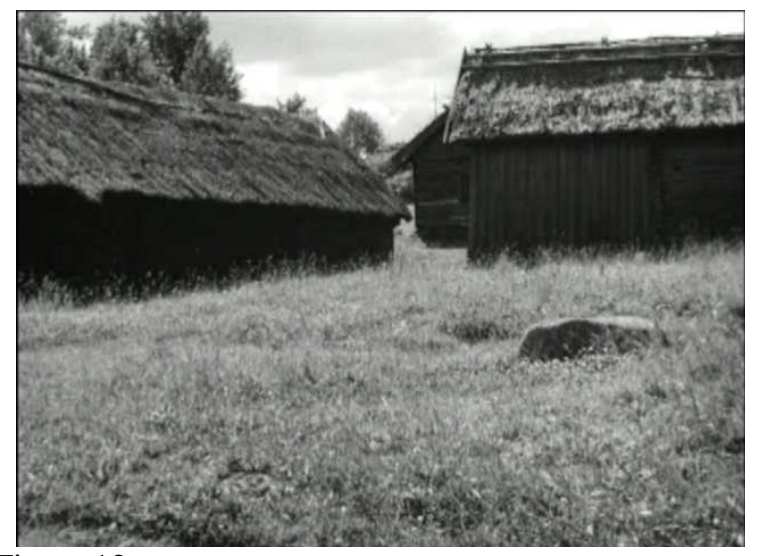

Figura 12

Quando os cavaleiros chegam das cruzadas em sua aldeia, ela se encontra vazia (Figura 12), como em Luz de Inverno nos planos em que mostram os arredores da igreja. Esse vazio pode ser entendido novamente como a ausência de Deus, principalmente se observarmos a sequência que se segue.

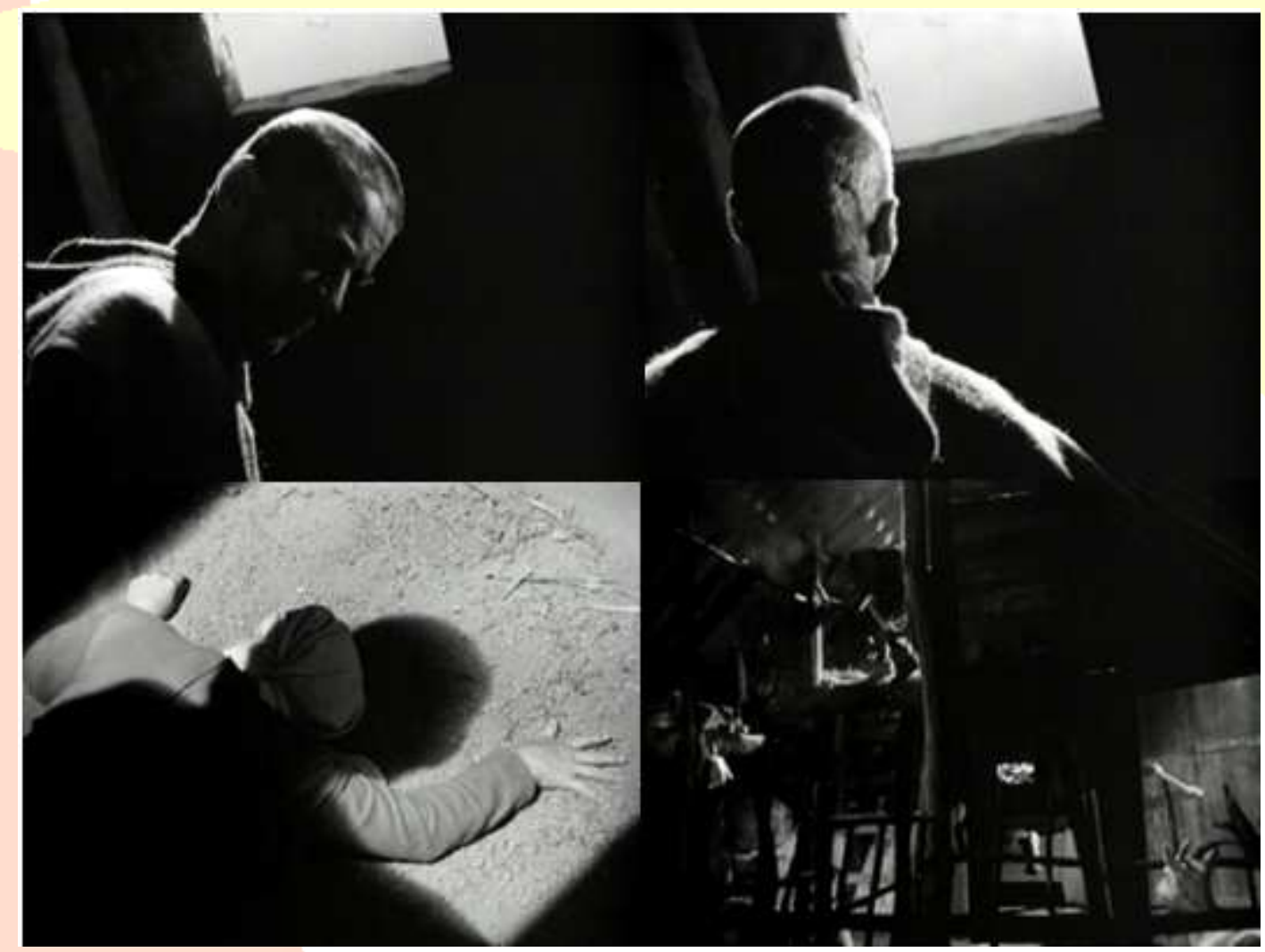

Figura 13 
Jöns entra numa das casas desta aldeia. Ele percebe e observa uma luz sobre sua cabeça, como uma luz celeste, porém o cavaleiro não percebe nenhum sinal divino apenas uma mulher morta sob essa luz. Em seguida, quem desce dessa luminosidade não é nenhum ser sagrado, mas um ladrão de jóias de mortos, o mesmo que convenceu o patrão dos cavaleiros a partirem para as cruzadas (Figura 13), além de ser o único que fala em nome de Deus e lidera a procissão dos flagelados. Ou seja, aquele que vem da "luz celeste" em nome do sagrado é um charlatão. Em um seguinte plano, o ladrão ameaça uma moça e comprova a não presença de Deus, dizendo "Não adianta gritar, nem mesmo Deus irá ouvila".

Quando os cavaleiros escoltam a trupe do teatro pela floresta, há um silêncio do qual reclamam. Eles gostariam de ouvir qualquer ruído ou até "uma voz humana, além da nossa" como diz Jöns, como se clamassem por Deus. O ferreiro que também os acompanhou diz "Ele quer que elas fiquem em silêncio", como se referisse a Deus, mas o que aparece no plano seguinte é uma carruagem carregada pelos soldados com uma mulher que vai ser queimada viva por acusarem de ter o diabo no corpo.

O filme inteiro ronda em torno da busca de um sentido para a vida, se Deus realmente existe. Como se pode observar na cena seguinte em que a mulher é queimada viva, Jöns pergunta a Block o que ela vê "Um anjo, o diabo, Deus, ou é apenas o vazio?" almejando uma resposta divina que não acontece.

No final, Block insiste em seu determinismo, agindo de má-fe, e reza dizendo que Deus deve estar em algum lugar e novamente não há nenhum sinal divino, somente a morte em sua frente.

O próprio jogo de xadrez com a morte é a metáfora perfeita para a vida como Sartre propõe. Onde se é livre para fazer escolhas, mas que inevitavelmente independente das opções nunca se escapa da morte que vem para representar o absurdo da vida. 


\section{Referências Bibliográficas}

Livros:

CABRERA, Julio. O cinema pensa: uma introdução à filosofia através dos filmes. Rio de Janeiro: Rocco, 2006.

SARTRE, Jean-Paul. O ser e o nada. Petrópolis: Vozes, 1997.

O existencialismo é um humanismo. 4.e.d. Lisboa: Editorial

Presença, 1978.

Dissertação:

OLIVEIRA, Cristiana Lopes de. Consciência e moral em Sartre. 2010. Dissertação (Mestrado em Filosofia) - Universidade Federal da Bahia, Salvador, 2010.

Internet:

NEGRIS, Adriano. A questão do existencialismo no filme Luz de Inverno. http://www.llpefil-uerj.net/filocin/218-a-questao-do-existencialismo-no-filme-luz-deinverno-ingmar-bergman. Acessado em 03/09/2011.

Filmes:

LUZ de inverno. Direção e roteiro de Ingmar Bergman. Suécia: SVENSK FILMINDUSTRI, 1963.

O SÉTIMO selo. Direção de Ingmar Bergman. Suécia: SVENSK FILMINDUSTRI, 1957.

SARTRE por ele mesmo. Direção de Alexandre Astruc e Michel Contat. França: SODAPERAGA PRODUCTIONS, 1976. 